\title{
Understanding by Design (UbD) for the Physics Learning about Parabolic Motion
}

\author{
Fransiska Retno Kuntari ${ }^{1, a}$, Ferdy Semuel Rondonuwu ${ }^{1,2, b}$, and Debora Natalia Sudjito ${ }^{1,2, c}$ \\ ${ }^{1}$ Department of Physics Education, Faculty of Science and Mathematics, Universitas Kristen Satya Wacana \\ ${ }^{2}$ Research Center for Science, Technology, and Mathematic Education (e-SisTeM), \\ Faculty of Science and Mathematics, Universitas Kristen Satya Wacana \\ Jalan Diponegoro, Salatiga 50711, Indonesia
}

e-mail: ${ }^{\mathrm{a}}$ nonofransiska@gmail.com, ${ }^{\mathrm{b}}$ ferdy.rondonuwu@uksw.edu, and ${ }^{\mathrm{c}}$ debora.natalia@uksw.edu

\begin{abstract}
In general, in preparing the lesson, teachers determine some components namely learning objectives, procedures, and evaluation and assessment instruments. Several problems in Physics learning on Parabolic Motion indicate possible flaws from the three components in designing the lesson. Understanding by Design (UbD) is applied as one of the alternative strategies to improve the lesson quality by considering the learning objectives, procedures, and evaluation by reversing the design, namely proposing the objectives first, evaluations as the second, and lesson steps as the last step. This is a qualitative research intended to construct an alternative design of Physics learning on Parabolic Motion using UbD. The initial Physics learning design was reviewed and analyzed by experts and revised until the final design. Understanding by Design (UbD) could be used as an alternative design construction as it helps teachers to relate the three main components, namely learning objectives, evaluations, and steps so it eased the students understand the materials comprehensively and obtain maximum score. Despite the development of current materials needs more improvement, Understanding by Design (UbD) can applied for many materials. Improvement and development the design is still needed.
\end{abstract}

Keywords: learning design, understanding by design, parabolic motion

\section{Understanding by Design (UbD) untuk Pembelajaran Fisika tentang Gerak Parabola}

\begin{abstract}
Abstrak
Pada umumnya pengajar membuat desain pembelajaran dengan membuat tujuan pembelajaran kemudian langkah pembelajaran dan terakhir soal evaluasi. Adanya masalah-masalah terkait pembelajaran fisika materi gerak parabola mengindikasikan kemungkinan adanya ketidakterkaitan antar komponen tujuan pembelajaran, langkah pembelajaran, dan evaluasi. Understanding by Design (UbD) diterapkan sebagai salah satu alternatif desain untuk memperbaiki kualitas pembelajaran dengan mengaitkan ketiga komponen tersebut, dengan cara membalik urutan desain pembelajaran; membuat tujuan pembelajaran terlebih dahulu, kemudian membuat soal evaluasi, dan terakhir membuat langkah pembelajaran. Tujuan penelitian ini adalah membuat alternatif desain pembelajaran fisika tentang gerak parabola dengan UbD. Desain pembelajaran yang telah dibuat menggunakan template UbD dikaji oleh reviewer. Hasil review dianalisis kemudian dilakukan revisi pada desain pembelajaran sehingga diperoleh desain final. Understanding by Design (UbD) dapat dijadikan sebagai salah satu alternatif
\end{abstract}

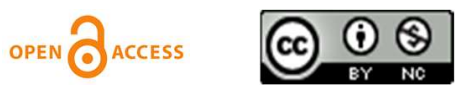


Jurnal Penelitian Fisika dan Aplikasinya (JPFA), 2019; 9(1): 32-43

desain pembelajaran materi gerak parabola. Understanding by Design (UbD) membantu dalam membuat keterkaitan antar komponen tujuan pembelajaran, langkah pembelajaran, dan evaluasi sehingga membantu siswa memahami materi dan mendapatkan nilai maksimal. Understanding by Design (UbD) relevan digunakan dalam membuat desain pembelajaran untuk berbagai materi. Perbaikan dan pengembangan dari desain ini masih diperlukan.

Kata Kunci: desain pembelajaran, understanding by design, gerak parabola

PACS: $01.40 . \mathrm{Di}, 45.50 .-\mathrm{j}$, 45.50.Dd

(C) 2019 Jurnal Penelitian Fisika dan Aplikasinya (JPFA). This work is licensed under CC BY-NC 4.0

Article History: Received: August 16, $2018 \quad$ Decided to resubmit (Round 1): March 5, 2019

Revised (Round 1): April 13, $2019 \quad$ Approved with minor revision: May 1, 2019

Accepted: June 26, $2019 \quad$ Published: June 30, 2019

How to Cite: Kuntari FR, Rondonuwu FS, and Sudjito DN. Understanding by Design (UbD) for the Physics Learning about Parabolic Motion. Jurnal Penelitian Fisika dan Aplikasinya (JPFA). 2019; 9(1): 32-43. DOI: https://doi.org/10.26740/jpfa.v9n1.p32-43.

\section{INTRODUCTION}

A teacher should prepare the lesson design or lesson plan before going to the classroom and giving the materials to the students. In general, in preparing the lesson, a teacher determines some key components namely learning objectives, learning steps or procedures and evaluations or assessments [1]. Of the three main components, ideally, it can be assumed that the learning steps are the way a teacher employs the instructional strategies to make students achieve certain competencies according to the learning objectives, then the achievement of competencies will be measured through evaluation or assessment instruments. It means that the learning steps should move based on the learning objectives and evaluation. In real practices, however, teachers generally only design learning steps based on teaching experience without looking at the learning objectives and evaluation instruments [1]. Likewise with the evaluations, the results of the evaluation should become the indicators for whether the planned learning objectives have been achieved by the students after the classroom activities. However, as the evaluations are made at the end of learning (before the tests) and are usually taken from books without being specifically related to the learning objectives, the evaluation questions are likely less to be suitable with the learning objectives and learning steps [1]. Therefore, the evaluation should be taken during designing the lesson starting from the learning objectives and relate to the learning steps. In preparation for learning, it is necessary to make relevant and interrelated objectives, evaluations, and learning steps.

Common issues for this matter is that the absent linkages between learning objectives and learning steps with evaluations. Generally, a teacher generates the evaluations after learning steps are made, while the evaluations are made or taken from textbooks without accurately relate them to the learning objectives and steps. As the consequence from these common practices, the impact on the students is that they may not know what they have to master or achieve from the classroom [1]. It is unfair for the students if they do not clear pictures of what they learn in the classroom and should be assessed or evaluated without sufficient knowledge and ability to do it. The lack of relation between objectives and learning steps with evaluation is believed to harm the students [2,3]. 
One of the issues observed in this study is the difficulty in Physics learning on Parabolic Motion for fresh students at the university level. Based on the results of interviews with three lecturers of Fundamental Physics subject at one private university in Central Java, it has been found that some obstacles are discovered in the process of learning Parabolic Motion among the students as they were still fixated on memorizing the formulas they have obtained during the high schools; the students perceived it is confusing when they had to be confronted with inputting the value of gravitational acceleration (negative or positive). The students also had difficulty in visualizing the magnitude and direction of force, velocity, and acceleration that work in parabolic motion, so it is suggested that learning using videos assisted with figures of working force, speed and acceleration vector. There were also difficulties in the teaching of Parabolic Motion material using other media beside whiteboards; students had difficulty also in applying the right equation to solve the problems during the evaluation. In addition, data related to students' school grade obtained for the Parabolic Motion materials from three different classes were still below the minimum standard of 70, namely 27.61, 32.97, and 42.63 respectively. Similar data were obtained by Noviandini [4] and Lila [5] that the students' school grade for the same material was below the minimum standard. Students perceived that the evaluations given were not in line with the learning materials, with their low grades during evaluation, they were categorized as not being able to achieve the objectives despite the incoherence and disconnection among the learning objectives, evaluation, and learning steps. This shows that there is a need to improve the quality of learning design, in particular for Physics education on Parabolic Motion. Understanding by Design (UbD) is one of the strategies that can be applied as an alternative solution to improve the quality of learning design [6-12].

$\mathrm{UbD}$ is also commonly called backward design because the process in designing the learning is conducted in reversed sequence; common practices in designing the lesson is from determining the learning objectives, followed by making learning steps, and evaluation, becomes determining objectives as the first step, followed by determining the evaluation instrument, and designing learning procedures as the last step. The design sequence of $\mathrm{UbD}$, according to Wiggins and McTighe, is divided into three parts. In stage 1, teachers should identify the desired competencies by making learning objectives. To determine learning objectives, teachers should examine which materials should be mastered by the students including the competencies students should have based on the existing curriculum standards. In Stage 2, teachers determine the proof of the achievement validation of acceptable goals by making evaluation instruments in the form either written tests, quizzes, and other assignments. It places the teacher to think as an assessor before making the learning design. In Stage 3, teachers should plan learning activities through proper instructional strategies. The proposed learning procedures and activities should refer to the learning objectives, namely which steps and activities should accommodate the set objectives. In other words, the proposed activities accommodate the learning objectives and the students are able to work on the materials during the evaluation session. With the reversed order of designing the lesson, there could be relationships among the key components of the learning design namely the objectives, evaluations, and learning steps $[1,13-15]$. 
This study is intended to propose an alternative design of Physics learning on Parabolic Motion for university level by using UbD concept for and investigate its effectiveness in the classroom. In addition, the proposed design is believed to give benefits in the process of learning of Parabolic Motion in Physics education.

\section{METHOD}

This is a research with the data in this study are presented qualitatively and narratively. The data include detailed descriptions of situations, activities, or events or certain phenomena; opinions of the experienced people, including their perception, attitudes, beliefs and ways of thinking; and documentation was based on the reporting documents and archive. Some techniques to obtain the data were observation, interview, and document analysis [16]. Figure 1 presents the procedures for data collection in related with designing the Physicseducation on Parabolic Motion that was designed by using Understanding by Design (UbD) concept. The arrows shows the sequential steps for designing the lesson.

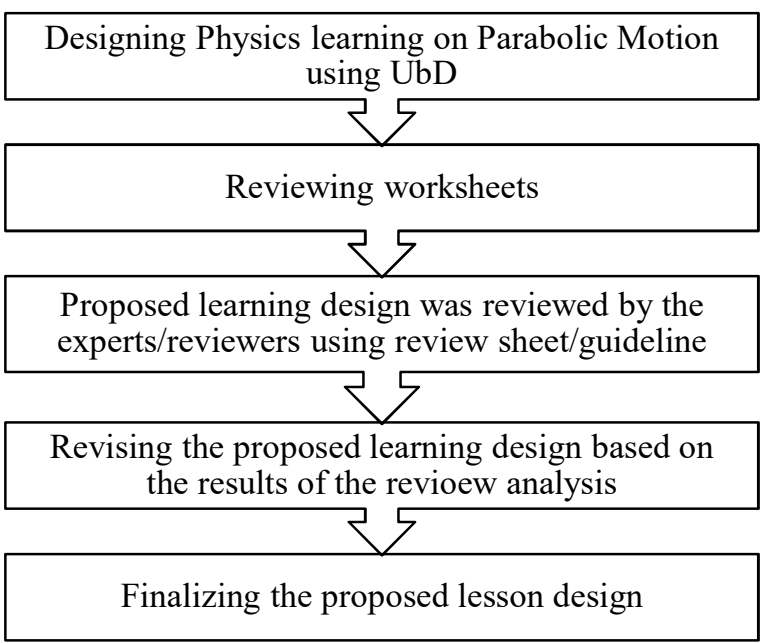

Figure 1. Research Procedures

Based on Figure 1, the process of designing proposed physics learning consisted of the learning objectives, learning steps, and evaluations on Parabolic Motion by using a simpler model of UbD. Figure 2 displays the simpler template of UbD adapted from the model proposed by Wiggins and McTighe [1] as it is only for some sequences in the classroom, not for the whole curriculum design.

\section{Stage 1: Objectives}

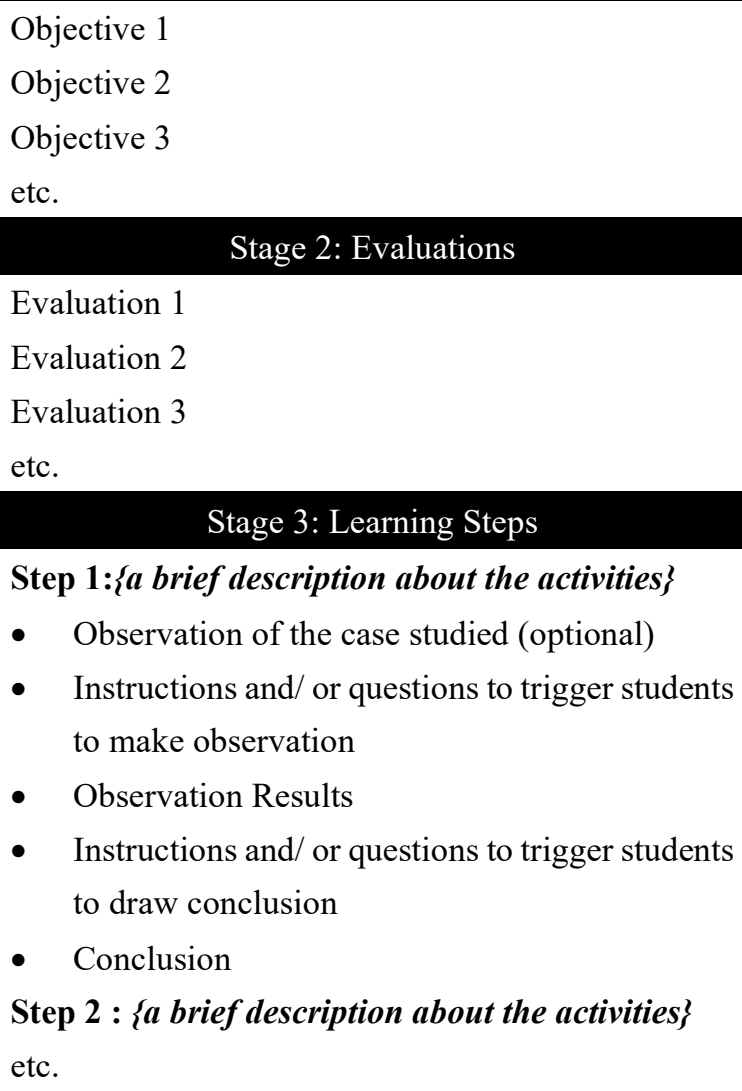

Figure 2. Simple Template for UbD Used in the Study

Stage 1 mostly contains of learning objectives. The learning objectives listed were based on assumptions for the key competencies that should be mastered by undergraduate students, not merely fixated on the existing curriculum.

Stage 2 describes the evaluation instruments. Evaluations were made by considering whether the problems can make students show their performance, so that ultimately the evaluation can be determined whether the learning objectives have been achieved by the students. The evaluation in 
this context was a final evaluation in the form of essays. The essay models were chosen with the rationale to allow students to explore their critical thinking. One point of the learning objectives could be evaluated with one or more questions or evaluation instruments. Some evaluation questions were made by the teachers themselves and some were taken from lecture references. Evaluation questions were made in open-ended model which are intended to stimulate critical thinking and test students' conceptual understanding; closedended questions were also included to examine the students' competency in applying basic equations in relevant subject matter.

Stage 3 contains the learning procedures. The formats of the learning steps employed scientific approach implicitly. The learning steps began with the students' preconceptions toward about the parabolic motion followed with observing cases relevant with the competencies. The instructional strategies employed mainly consisted of instructions and questions to prompt students' engagement and active participations to make observations. Learning methods included discussion, assignments, and demonstrations. The strategy emphasized in UbD was to construct learning steps to make students successfully worked on the evaluations.

Furthermore, review sheet was made to review the learning design. It contained indicators that assess the relevance of evaluation with learning objectives, objectives with learning steps, learning steps with the evaluation, depth of material for undergraduate level, suitability of the method of delivering material, suitability of learning media used to explain the learning materials, suitability of the instructions in the learning steps provided to achieve the intended results, sufficient allocation of time, and open-ended and closed-ended questions for the evaluations. These indicators were made on the basis of core assessments of the UbD (i.e. the linkages among objectives, evaluation, and learning steps), students' competencies, material characteristics, students' characteristics, real learning time in class, and assessment of students' cognitive level. The assessment indicators in the review sheet were made specifically referring to everything that was intended to facilitate the reviewers in conducting the assessment. The proposed design of Physics learning on Parabolic Motion was reviewed by the reviewersbased on the review sheet or guideline. The review sheets were filled up by three expert reviewers consisting of both Physics teachers and lecturers.

After the review step was conducted by the reviewers, an analysis of the review was carried out based on the feedback given. The researchers as the observers played an important role in designing the proposed lesson, which the quality of qualitative research is determined by the ability to collect data and interpret the data [16]. Not all inquiry from the review results were taken, only those relevant feedback which was intended for the improvement of the quality of the proposed learning design. The reviews still became the bases to revise the Physics learning design to finalize the proposed lesson design. The same analytical method also used by Pertiwi, et al and Setyanto, et al to examine the learning design in their research $[17,18]$.

\section{III.RESULTS AND DISCUSSION}

On Stage 1, the learning objectives were made in certain wordings that after the classroom, students are be able to describe the directions of the vectors of force, velocity, and acceleration in a particular position of an object moving parabolic; students are be able to determine physical quantities $(x, y, v$, and $t)$ of an object that moves in parabolic motion; students are be able to predict the shape of the motion of an object if the physical quantities of objects $\left(\theta, v_{0}\right)$ are changed. 
These objectives were made with the expectation to obtain the following competencies that students are expected to (consecutively based on objectives): understand the concepts of $F, v, a$ on parabolic moving object, determine the physical quantities on parabolic moving object, and predict the shape of the motion track of an object if the physical quantities of the object are changed.

On Stage 2, six evaluations were made, namely: students are asked to describe the direction of the vectors of force, acceleration, and velocity of a parabolic moving object and the students were also asked to determine the value of physical quantities such as $y, t$, and $x$, students are assigned to calculate the value of physical quantities such as $y, t$, and $x$; students are asked to predict the sequence of several parabolic trajectories based on physical quantities $t, v_{0 x}$, dan $v_{0 y}$; students are asked to predict the sequence of several parabolic trajectories based on their final velocity; students are asked to predict the sequence of several parabolic trajectories based on velocity before touching the ground; and students are asked to predict the trajectory shape of motion track of a charged particle between two different charge plates.

Evaluation 1 examined students' performance about their comprehension about the force, acceleration, and velocity of parabolic moving objects that can refer to the achievement of Objective 1, as well as student's performance about physical quantities such as $y, t$, and $x$ which can refer to the achievement of Objective 2. Evaluation 2 aimed to test students' performance about their comprehension of distance and velocity of parabolic motion to referring to the achievement of Objective 2. Evaluation 3, 5, and 6 were aimed to test the performance of the students to predict the relationships of physical quantities with shape of trajectory, to show the achievement of Objective 3 .
Evaluation 4 tested students' performance about their understanding upon the concept of velocity from a moving parabolic object that can show the achievement of Objective 1.

On Stage 3, learning steps were made with an allocation of time for 2 hours and 30 minutes, as follows: Step 1, students were instructed to describe the vector direction of various physical quantities in parabolic motion, so that it provided the students with the concepts of $F, v, a$ on a parabolic moving object, so that students could work on Evaluations 1a and 4. If the students would able to work on the Evaluations 1a and 4, Objective 1 had been achieved. In this step, initially each students were given a piece of paper containing a picture of a basketball in parabolic motion track. After that, the students were asked to describe the direction of the vectors of force, acceleration, and velocity at each position. The next step was discussion, in which the students were guided to discuss to determine the correct answers from the previous activities.

Step 2, students were instructed to determine the equations in parabolic motion. In this step, the teacher equipped the students to be able to determine physical quantities on a parabolic moving object, so that they could work on the Evaluation 1b-e and 2. If students were able work on the Evaluation 1b-e and 2, Objective 2 had been achieved. On Step 2, the students were divided into groups. Each group was assigned to determine equations such as $x, y, v$, and $t$ at one of the specified positions. After discussing in group, each group was asked to present the results of their discussion in front of the class. Additional discussion involving the whole class was performed and the teachers acted as the facilitator.

Step 3 was divided into Simulation 1 and Simulation 2. In Simulation 1, the students were guided to find relationship of $\alpha$ with $x_{\max }, t_{\max }, y_{\max }$, and $v_{\text {final }}$, while in Simulation 2, 
the students were instructed to find the relationships of $v_{0}$ with $x_{\max }, t_{\max }, y_{\max }$, and $v_{\text {final }}$. Both simulations were demonstrated by the teacher using the Physics Education and Technology (PhET) simulations of projectile motion. After the simulation, students were encouraged to draw conclusions.

Step 4, the students were provided with the materials of parabolic motion that applied to charged objects between two different charged plates. Steps 3 and 4 equipped the students to be able to predict the shapes of the motion tracks of an object if its physical quantities are changed, so that students are able to work on the Evaluations 3, 5, and 6. If students were able to work on Evaluations 3, 5 , and 6 , Objective 3 had been reached.

Table 1 summarizes the relationship among learning objectives, evaluation, and learning steps before it is delivered to the reviewers. There were eight reviews that were considered to revise the initial physics learning design on Parabolic Motion.

Table 1. Linkages of Learning Objectives, Evaluation, And Learning Steps of the Proposed Lesson Design Before Being Reviewed

\begin{tabular}{ccc}
\hline Objectives & Evaluations & Learning Steps \\
\hline 1 & $1 \mathrm{a}$ & 1 \\
& 4 & \\
2 & $1 \mathrm{~b}$ & 2 \\
& $1 \mathrm{c}$ & \\
& $1 \mathrm{~d}$ & \\
& $1 \mathrm{e}$ & \\
& 2 & \\
& 3 & 3 Simulation 1 \\
& 5 & 3 Simulation 2 \\
& 6 & 4 \\
\hline
\end{tabular}

The First Review. Objective 3 which said, "Students are able to predict the shape of the motion track of an object if the physical quantities of objects $\left(\theta, v_{0}\right)$ are changed"is not in accordance with Step 3 Evaluations 3 and 4 as the information about the trajectory which has been provided while students were asked to determine the physical quantities. Therefore, the learning objectives were added, "Students are able to predict the physical quantities of objects from various parabolic trajectories"; while Objective 3 remained because it can be evaluated with Evaluation 6 and accommodated by using Step 4 . Table 2 shows the relationship among learning objectives, evaluations, and learning steps after being given the suggestions by the reviewers. The part in the red box below is the revised version of the initial lesson design.

Table 2. Linkages of Learning Objectives, Evaluation, And Learning Steps After Review

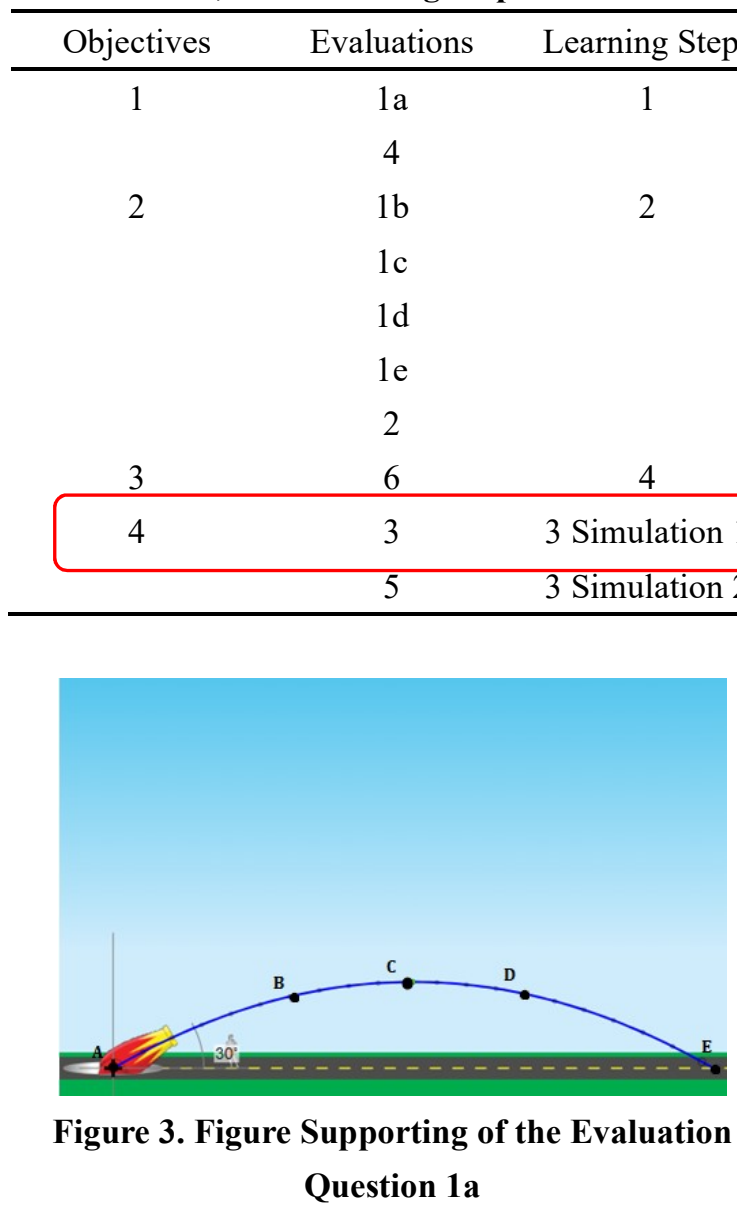

The Second Review. Evaluation 1a, at position E, it should be provided with a statement defining that a position the point at which an object reaches when it momentarily touches the ground (Figure 3). If it is not included, it may cause the different 
perceptions that the object has stopped so the speed is 0 . This is not in accordance with the purpose of learning. It is important to make question instructions as clear as possible to minimize students' misinterpretation caused by unclear instruction by the teachers.

The Third Review. Step 1 was initially intended to teach the students to draw velocity, force, and acceleration vectors. According to reviewers, this sequence should be to teach drawing vectors of force, acceleration, and speed. This is considered as a right way and may guide the students to make more precise vector figures. Additionally, the most important aspect in this section is to teach the students about the foundational meaning of parabolic motion, namely uniform linear motion on an axis, and accelerated linear motion on the other axis. By teaching the force first, students are led to understand that the acting force is a gravitational force which only works on the $y$ axis. The gravitational force causes acceleration of gravity towards $y$ only, while there is no acceleration in the direction of $\mathrm{x}$. In other words, on the $x$ axis applies for uniform linear motion and on the $y$ axis applies for accelerated linear motion. This is the basic concept that needs to be emphasized in the learning of parabolic motion subject matter.

The Fourth Review. The equations provided in Step 2 were the equations that apply to parabolic motion with symmetrical trajectories and $y_{0}=0$. This part was criticized by reviewers because it does not teach about parabolic motion in general beyond these requirements. Although there was a suggestion from the reviewer, no changes were made in Step 2 because it was in accordance with the competencies targeted for students in this study program; therefore, as part of enrichment for this subject, teachers who will be implementing this lesson design are allowed to develop the equations that will be given to the students.
The Fifth Review. It is necessary to add more questions for practices after the students are asked to find equations in parabolic motion. According to the reviewer, the equations in parabolic motion are numerous, and although students had found and memorized the formula, students might not be able to apply the exact equation to work on the problem (evaluation).

The Sixth Review. In demonstrating parabolic motion using PhET simulation in Step 3 of Simulation 1 and Simulation 2, it is necessary to write down the physical quantities observed in the demonstration so that students had the data in their notebook facilitating conclusions.

The Seventh Review. Step 3 Simulation 2 , the conclusion that reads "The initial velocity of an object is directly proportional to the farthest distance, the time to reach the farthest point, the maximum height of the object, and the instantaneous velocity of the object before reaching the ground". It is better to be written as follow: "The greater of initial velocity of the object, the farthest distance and faster time to reach the farthest point, the maximum height of the object, and the instantaneous speed of the object before reaching the ground."

The Eighth Review. The suggestion for improvement of some of the equations in Step 2 and some editorial suggestions as well as improvements to the drawing on the learning steps and evaluations are accepted. The following was one of the changes in parabolic motion in one of the student's worksheets (it is used to explore students' preconceptions in Step 1). The drawing or figure was changed to resemble a basketball track that moved in parabolic rather than just giving a figure that forms a parabolic path as shown in Figure 4. In showing the parabolic trajectory to students which would then be studied by them, it was necessary to note whether the track was in the form of a parabolic trajectory because it 
would affect the vectors of the component drawn.

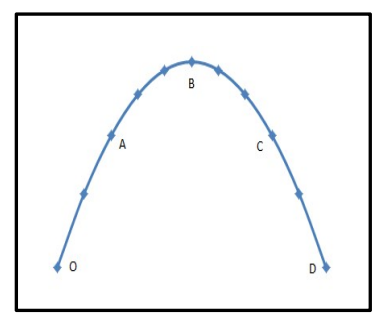

(a)

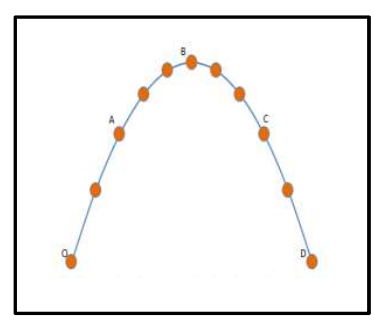

(b)
Figure 4. Parabolic Motion Trajectories in Step 2

(a) Before Review (b) After the Review

There were also important things in this study besides the components being reviewed, i.e: it is important to provide variations in the parabolic motion cases and also variations of the evaluations and questions given to the students in order to minimize boring instruction and provide a new and alternative atmosphere for the students as in Step 4 and Evaluation 6. In addition, this is also believed to improve the students' thinking skills in applying the concept of parabolic motion, not just by memorizing that concept; it is important to provide open-ended evaluations (meaning that the evaluation process requires conceptual understanding, not just memorizing theories or formulas) because these types of questions can be used to determine students' understanding and knowledge, as well as to stimulate students' critical thinking; in determining the learning objectives, evaluations, and learning steps, the most important thing is to make connections among those three aspects $[17,18]$. Thus, from the review and revision process until the final design was made, it shows that UbD can be used as the alternative learning design, in this case is for Parabolic Motion learning design.

In another study about parabolic motion, Wijaya, et al used projectile launcher media of Physics learning as a physical practicum tool to support the material [19]. In that study, students were practiced to determine the longest distance from a ball with various mass variations. The advantage of that research is that the projectile launcher learning media shows significant results with the increase in cognitive, affective, and psychomotor aspects of the students. The shortcoming of the media is that the inability of the tool to determine the maximum height and interval time of parabolic motion. The same problem also experienced by Indah and Prabowo who made simple props for parabolic motion material [20]. When compared with this design, the supporting activities carried out used a PhET simulation to determine the farthest distance. This simulation helps students not only to determine the farthest distance, but it can also be used to determine the furthest point and interval time of parabolic moving objects at a shorter time compared to Wijaya's, et al research. The learning process can also be done not only in schools, but can be performed at homes or any place [21] so that it is more practical, but the lack of this simulation is that it does not involve the psychomotor aspects of students. If the teachers want to instill material understanding by emphasizing students' cognitive, affective, and psychomotor aspects even though in a relatively long time, then learning is recommended using practical methods. However, if teachers want to instill more material mastery more practically and in a shorter time, it is suggested to use simulation method.

In the other study about UbD in Indonesia, a good result came from researches by Pertiwi, et al and Setyanto, et al They used UbD to make learning design about electric circuit and Newton's Second Law. Understanding by Design helps the teacher to relate the objectives, evaluations, and learning steps and hopefully could be the alternative to make learning design $[17,18]$. It means that UbD works properly for many materials. 
Evaluation results that were not in accordance with teachers' expectations were caused by two factors namely, students had not understood the concept and students had misconceptions so that what is taught is not in line with the conception that has been built in their head $[22,23]$. This design of learning about parabolic motion using $\mathrm{UbD}$ has been made by considering the interrelationship between objectives, evaluations, and learning steps and it is expected that the design of learning that has been made can be used by teachers to help students understand the concept of parabolic motion and obtain maximum score.

In connection with misconceptions, there were various misconceptions related to parabolic motion. In a study done by Karim and Saepuzaman, misconceptions of parabolic motion is found in physics teacher candidates [24]. This indicates the difficulty of understanding parabolic motion found in people who have received the material repeatedly. The positive thing that can be taken from the research is that the teacher should investigate the students' conception before giving the material. This is also recommended in a journal written by Noviandini, so that teachers should be careful in designing of a learning because they must know the students' conceptions that they already have [4]. One solution offered is to remediate the concept of kinematics using the fast feedback and demonstration-interaction method. In addition, Arie et al offered a solution to remediate the misconceptions of parabolic motion material with a cooperative model type 'Kancing Gemerincing' [25]. According to Suparno, there are various ways to overcome misconceptions, including: first, teachers must look for or reveal students' misconceptions. Second, teachers must find the cause of the misconception. Third, teachers must find the appropriate treatment to overcome this misconception [26]. In this study, in Step 1, a preconception of the excavation was conducted towards students to detect their abilities even though it was not used to detect misconceptions that might occur to students. In subsequent studies, it is better to perform misconception detection, especially for concepts that are prone to misconceptions.

\section{CONCLUSION}

Understanding by Design (UbD) can be utilized as the alternative to design a lesson in particular for Physics learning on Parabolic Motion by emphasizing the interrelation among learning objectives, learning steps, and evaluation. With this design, it is expected that it will be used by the teachers to help the students in understanding the material and obtain maximum score. The important things from this research are: it is better if every components in objectives, learning steps, and evaluation valid and clear, it is better if the teacher makes variation in teaching materials and in evaluations (especially open-ended evaluations), the right way that can guide students to make more precise vector figures are drawing vectors of force as the first, the second is acceleration, and speed as the last, it is suggested to use simulation method if the teacher instills more materials mastery more practically and in a shorter time, it is better to perform misconception detection, especially for concepts that are prone to misconceptions like Parabolic Motion, understanding by Design can be utilized for many teaching materials. The development of the objectives, evaluation, and learning steps can be done because there are still deficiencies in the design resulting from this study.

\section{REFERENCES}

[1] Wiggins $\mathrm{G}$ and McTighe J. Understanding by Design Second Edition Alexandria: Association for Supervision and Curriculum Development (ASDC). Colombian Applied 
Jurnal Penelitian Fisika dan Aplikasinya (JPFA), 2019; 9(1): 32-43

Linguistics Journal. 2005; 19(1): 140-142. DOI :

http://dx.doi.org/10.14483/calj.v19n1.11490.

[2] Nurdin S. Aspek Aplikasi Konsep Sains dalam Evaluasi Pembelajaran IPA di MI. Jurnal Pionir. 2013; 1(1): 115-130. Available from:

https://jurnal.arraniry.ac.id/index.php/Pionir/article/view/16 $\underline{0 / 141 .}$

[3] Sanjaya W. Perencanaan dan Desain Sistem Pembelajaran. Jakarta: Kencana; 2015.

[4] Noviandini D, Sunarno W, and Cari. Remediasi Miskonsepsi Kinematika dengan Umpan Balik Cepat Menggunakan Simulasi Komputer dan Demonstrasi. Inkuiri. 2014; 114. DOI:

https://doi.org/10.20961/inkuiri.v3i01.9702.

[5] Lila K. Pengembangan Tes Diagnostik Fisika Materi Gerak Parabola untuk Siswa Kelas XI di Kota Pontianak. Jurnal Pendidikan dan Pembelajaran. 2017; 6(9): 1-8. Available from:

http://jurnal.untan.ac.id/index.php/jpdpb/arti cle/view/21854.

[6] Corvo AF. Utilizing The National Research Council's (NRC) Conceptual Framework for The Next Generation Science Standards (NGSS): A Self Study in My Science, Engineeringm and Mathematics Classroom. Doctoral Dissertation. Unpublished. New York: Columbia University; 2014. Available from:

https://academiccommons.columbia.edu/doi/ 10.7916/D8RV0W3K/download.

[7] Molina W. Teachers' Views of Backwards Planning in a Suburban Elementary School in Hawaii. Doctoral Dissertation. Unpublished. Minessota: Walden University; 2013.

[8] Anderson AR. Implementing Literature Circles: An Experimental Study in an English Language Learners' Classroom. Doctoral Dissertation. Unpublished. Minneapolis: Capella University; 2012.
[9] Schoellhorn L. "Bringing History to Life" Exploring the Historic Cemetery as a Primary Classroom Resource. Master Thesis. Unpublished. Missouri: Webster University; 2012.

[10] Takacs JA. Using Formative Assessment in Professional Learning Communities to Advance Teaching and Learning. Doctoral Dissertation. Unpublished. Minessota: Walden University; 2010.

[11] Yurtseven N and Altun S. Understanding by Design (UbD) in EFL Teaching Teachers' Professional Development and Students' Achievment. Educational Sciences: Theory and Practice. 2017; 17(2): 437-461. Website. DOI:

https://doi.org/10.12738/estp.2017.2.0226.

[12] Almaseid TF. The Impact of Using Understanding by Design (UbD) Model on 8th-Grade Student's Achievement in Science. European Scientific Journal. 2017; 13(4): 301-315. DOI: http://dx.doi.org/10.19044/esj.2017.v13n4p3 $\underline{01}$.

[13] Fox BE and Doherty JJ. Design to Learn, Learn to Design: Using Backward Design for Information Literacy Instruction. Communications in Information Literacy. 2012; 5(2): 144-155. DOI:

https://doi.org/10.15760/comminfolit.2012.5 .2 .109 .

[14] McTighe J and Thomas RS. Backward Design for Forward Action. Educational Leadership: Using Data to Improve Student Achievement. 2003; 60(5): 52-55. Available from:

http://www.ascd.org/publications/educationa l-leadership/feb03/vol60/num05/BackwardDesign-for-Forward-Action.aspx.

[15] Sgro SD and Freeman SA. Teaching Critical Thinking Using Understanding by Design. Proceeding of 2008 ASEE Annual Conference and Exposition. Department of Agricultural and Biosystems Engineering, Iowa State University. 2008; 224. Available 
Jurnal Penelitian Fisika dan Aplikasinya (JPFA), 2019; 9(1): 32-43

from:

https://ib.dr.iastate.edu/abe_eng_conf/224.

[16] Yusuf AM. Metode Penelitian Kuantitatif, Kualitatif dan Penelitian Gabungan. Jakarta: Prenada Media; 2016.

[17] Pertiwi S, Sudjito DN, and Rondonuwu FS. Perancangan Pembelajaran Fisika tentang Rangkaian Seri dan Paralel untuk Resistor Menggunakan Understanding by Design (UbD). Jurnal Sains dan Edukasi Sains. 2019; 2(1): 1-7. DOI: https://doi.org/10.24246/juses.v2i1p1-7.

[18] Setyanto JR, Sudjito DN, and Rondonuwu FS. The Use of Understanding by Design in Designing the Physics Lesson Plan About Newton's Second Law. Journal of Science and Science Education. 2018; 2(2): 69-80. Available from:

https://ejournal.uksw.edu/josse/article/view/ 1936.

[19] Wijaya RC, Damris M, and Kamid K. Pengembangan Media Pembelajaran Fisika Projectile Launcher sebagai Alat Praktikum Fisika pada Materi Gerak Parabola Fisika Kelas XI IPA. Edu-Sains: Jurnal Pendidikan Matematika dan Ilmu Pengetahuan Alam. 2014; 3(2): 46-56. Available from:

https://onlinejournal.unja.ac.id/edusains/article/view/1895.

[20] Indah DS. Pengembangan Alat Peraga Sederhana Gerak Parabola untuk Memotivasi Siswa pada Pembelajaran Fisika Pokok Bahasan Gerak Parabola. Inovasi Pendidikan Fisika. 2014; 3(2): 89-94. Available from: https://jurnalmahasiswa.unesa.ac.id/index.ph p/inovasi-pendidikanfisika/article/view/8075.
[21] Karanggulimu L, Sudjito DN, and Noviandini D. Desain Modul Praktikum Mandiri Tentang Gerak Parabola Menggunakan Simulasi PhET "Projectile Motion". Proceeding of Seminar Nasional Pendidikan, Sains dan Teknologi. Faculty of Mathematics and Natural Sciences, Universitas Muhamadiyah Semarang. 2017; 216-226. Available from: https://jurnal.unimus.ac.id/index.php/psn120 12010/article/view/3062.

[22] Suwarto. Pengembangan Tes Diagnostik dalam Pembelajaran. Yogyakarta: Pustaka Belajar; 2013.

[23] Berg EV. Miskonsepsi Fisika dan Remediasi. Salatiga: Universitas Kristen Satya Wacana; 1991.

[24] Karim S and Saepuzaman D. Analisis Kesulitan Mahasiswa Calon Guru Fisika dalam Memahami Konsep Gerak Parabola. Proceeding of Seminar Nasional Fisika (SNF) 2016. Department of Physics, Universitas Negeri Jakarta. 2016; 1-5. Available from:

http://journal.unj.ac.id/unj/index.php/prosidi ngsnf/article/view/4031.

[25] Yarso AA, Sahala S, and Arsyid SB. Remediasi Miskonsepsi Siswa Menggunakan Model Kooperatif Tipe Kancing Gemerincing pada Gerak Parabola di SMA. Jurnal Pendidikan dan Pembelajaran. 2014; 3(6): 6124. Available from:

http://jurnal.untan.ac.id/index.php/jpdpb/arti cle/view/6124.

[26] Suparno P. Miskonsepsi dan Perubahan Konsep dalam Pendidikan Fisika. Jakarta: Grasindo; 2013. 